\title{
Strategi Pengendalian dan Pengawasan Sempadan Sungai. (Studi Kasus : Kali Surabaya di Kecamatan Driyorejo dan Wringinanom Kabupaten Gresik)
}

\author{
Suprapti, Usman Arief, Siti Zahrok, Heru Purwadio
}

\begin{abstract}
Abstrak
Menurut Ecoton (2014), di Kecamatan Driyorejo dan Wringinanom Kabupaten Gresik sepanjang kanan kiri Kali Surabaya terdapat lebih dari 1.000 bangunan permukiman, tempat usaha dan sarana umum yang dibangun secara permanen di atas sempadan Kali Surabaya. Sementara itu Dinas Pengairan Provinsi jawa Timur mengidentifikasikan di sepanjang Kali Surabaya yang melewati Kecamatan Wringinanom dan Driyorejo terdapat 1.191 bangunan yang dibangun di daerah sempadan sungai. Di antaranya adalah pembangunan gudang dan ruko City Nine di Desa Cangkir Kecamatan Driyorejo dan pembangunan perumahan yang menggunakan alat berat yang memakan sempadan Kali Surabaya di Desa Cangkir Kecamatan Driyorejo.

Dalam Keppres Nomor 32 Tahun 1990 tentang Pengelolaan Kawasan Lindung; Peraturan Menteri Pekerjaan Umum No 63.PRT/1992 tentang Garis Sempadan Sungai, Daerah Manfaat Sungai, Daerah Penguasaan Sungai dan bekas Sungai; serta Peraturan Pemerintah Nomor 38 Tahun 2011 Tentang Sungai; dilarang membangun gedung di dalam daerah sempadan sungai, karena menyebabkan penyempitan sungai yang bisa berujung terjadinya bencana banjir.

Pelanggaran terhadap pemanfaatan sempadan sungai terjadi karena lemahnya pengendalian dan pengawasan yang dilakukan pemerintah, dalam hal ini sebagai pengelola sempadan sungai adalah Balai besar Wilayah Sungai (BBWS) Brantas yang merupaan kepanjangan tangan dari Kementrian Pekerjaan Umum yang berwenang mengelola Kali Brantas dan Kali Surabaya. BBWS tidak aktif melakukan pemantauan terhadap pelanggaran dan tidak memiliki komitmen kuat dalam penegakan hukum secara tegas sehingga terjadi pelanggaran pemanfaatan sempadan sungai seperti sekarang. BBWS kurang koordinasi dan sosialisasi kepada Pemerintah Kabupaten atau Pemerintah Kota dan Pemerintah Desa yang dilalui Kali Surabaya sehingga seolah-olah Kali Surabaya menjadi kawasan tanpa pengelola.

Pelanggaran terhadap pemanfaatan sempadan Kali Surabaya merupakan bentuk pelanggaran terhadap pemanfaatan ruang. Dalam Pasal 35 Undang-undang No. 26 Tahun 2007 tentang Pemanfaatan Ruang disebutkan bahwa pengendalian pemanfaatan ruang dilakukan melalui Peraturan Zonasi, perizinan, pemberian insentif/disinsentif, dan pemberian sanksi. Strategi pengendalian dan pengawasan sempadan sungai di Kecamatan Driyorejo dan Wringinanom dilakukan dengan menetapkan Rencana Detail Tata Ruang (RDTR) dan Peraturan Zonasi Kecamatan Driyorejo dan Kecamatan Wringinanom yang di-perda-kan. Pengendalian melalui perizinan merupakan filter berjenjang melalui penerbitan Izin Prinsip, Izin Lokasi, Izin Site Plan, Izin Mendirikan Bangunan, dan izin lainnya yang diperlukan, oleh Badan Penanaman Modal dan Perizinan Kabupaten Gresik yang berkoordinasi dengan Dinas Pekerjaan Umum dan Tata Ruang Kabupaten Gresik, Badan Pertanahan Kabupaten Gresik, dan instansi lain yang berkaitan. Pengendalian melalui pemberian disinsentif merupakan upaya untuk menghambat pemanfaatan ruang yang tidak dikehendaki perkembangannya. Pemberian sanksi berupa sanksi administratif mulai peringatan tertulis sampai pembongkaran bangunan.
\end{abstract}

Kata kunci : pengendalian, pengawasan, sempadan sungai 
Pelanggaran pemanfaatan ruang di daerah sempadan sungai banyak dijumpai di daerah aliran sungai besar di Jawa Timur. Daerah sempadan sungai bertanggul maupun sungai tak bertanggul banyak yang di atasnya dibangun bangunanbangunan gedung, baik rumah tinggal, toko, kantor, gudang, ruko, fasilitas umum, dan lainnya.

Di Kecamatan Driyorejo dan Wringinanom Kabupaten Gresik sepanjang kanan kiri Kali Surabaya terdapat lebih dari 1.000 bangunan permukiman, tempat usaha dan sarana umum yang dibangun secara permanen di atas sempadan Kali Surabaya (Ecoton; 2014). Dinas Pengairan Provinsi jawa Timur mengidentifikasikan di Kecamatan Wringinanom dan Driyorejo terdapat 1.191 bangunan yang dibangun di daerah sempadan Kali Surabaya. Antara lain pembangunan gudang dan ruko City Nine di Desa Cangkir Kecamatan Driyorejo dan pembangunan perumahan yang yang memakan sempadan Kali Surabaya di Desa Cangkir Kecamatan Driyorejo.

Pemanfaatan ruang di daerah sempadan sungai diatur dalam Keppres Nomor 32 Tahun 1990 tentang Pengelolaan Kawasan Lindung; Peraturan Menteri Pekerjaan Umum No 63.PRT/1992 tentang Garis Sempadan Sungai, Daerah Manfaat Sungai, Daerah Penguasaan Sungai dan bekas Sungai; serta Peraturan Pemerintah Nomor 38 Tahun 2011 Tentang Sungai. Di dalam peraturan perundangan disebutkan bahwa daerah sempadan sungai dilarang digunakan untuk bangunan gedung.

Walaupun peraturan perundang-undangan dengan jelas telah melarang pemanfaatan sempadan sungai untuk bangunan gedung, tetapi dalam kenyataannya pelanggaran terhadap pemanfaatan ruang di daerah sempadan sungai masih tetap terjadi dan berlangsung hingga sekarang. Hal ini antara lain disebabkan karena lemahnya pengendalian dan pengawasan yang dilakukan pemerintah, dalam hal ini sebagai pengelola sempadan sungai adalah Balai besar Wilayah Sungai (BBWS) Brantas yang berwenang mengelola Kali Brantas dan Kali Surabaya. BBWS tidak aktif melakukan pemantauan terhadap pelanggaran dan tidak memiliki komitmen kuat dalam penegakan hukum secara tegas sehingga terjadi pelanggaran pemanfaatan sempadan sungai seperti sekarang. Selain itu BBWS kurang koordinasi dan sosialisasi kepada Pemerintah Kabupaten atau Pemerintah Kota dan Pemerintah Desa yang dilalui Kali Surabaya. 
Permasalahan tersebut mengindikasikan belum efektifnya pengendalian dan pengawasan pemanfaatan ruang di daerah sempadan sungai terhadap ketentuan peraturan perundangan yang berlaku. Berkaitan dengan masalah tersebut, studi ini bertujuan untuk merumuskan strategi pengendalian dan pengawasan daerah sempadan sungai melalui pendekatan regulasi.

\section{Lingkup Studi}

Lingkup studi terdiri dari lingkup wilayah dan lingkup substansi. Lingkup wilayah studi adalah daerah sempadan Kali Surabaya yang berada di Kecamatan Driyorejo dan Kecamatan Wringin Anom Kabupaten Gresik. Di wilayah studi terdapat sepuluh desa yang dilewati Kali Surabaya, yaitu Desa Kedung Anyar, Sumber Rame, Wringin Anom, Lebani Waras, dan Sumengko, yang masuk Kecamatan Wringin Anom; serta Desa Pasinan Lemah Putih, Krikilan, Driyorejo, Cangkir dan Desa Bambe, yang masuk Kecamatan Driyorejo (Perum Jasa Tirta; 1994). Lingkup wilayah studi ditunjukkan pada Gambar 1 dan Gambar 2.

Lingkup substansi yang dibahas dalam studi ini adalah pengendalian dan pengawasan sempadan sungai ditinjau dari aspek regulasi.

\section{Peraturan yang Berkaitan Dengan Sempadan Kali Surabaya}

Peraturan yang digunakan untuk merumuskan strategi pengendalian dan pengawasan Sempadan Kali Surabaya adalah :

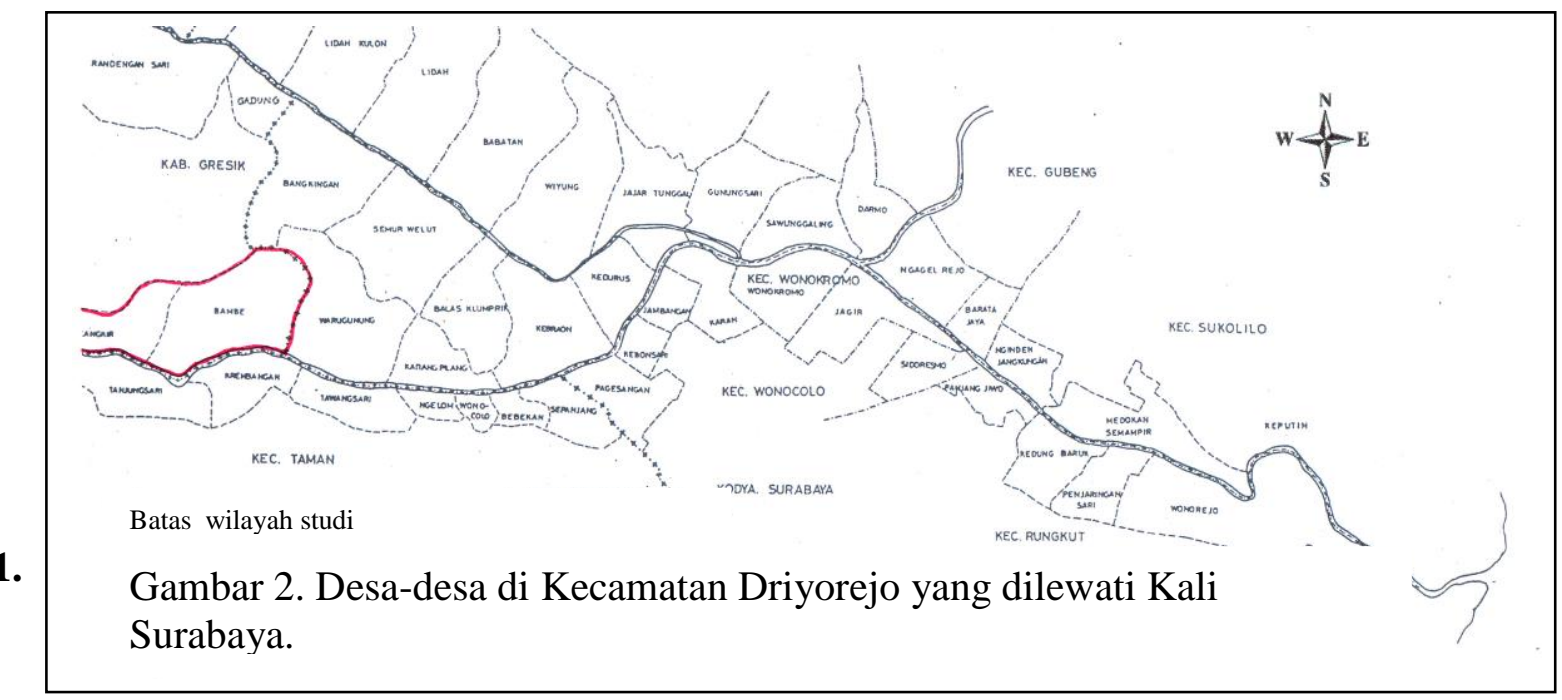


Ketentuan dalam Undang-undang Nomor 26 Tahun 2007 Tentang Penataan Ruang yang bertautan dengan pengendalian dan pengawasan pemanfaatan ruang adalah :

\section{Pasal 38}

(1) Dalam pelaksanaan pemanfaatan ruang agar pemanfaatan ruang sesuai dengan rencana tata ruang wilayah dapat diberikan insentif dan/atau disinsentif oleh Pemerintah dan Pemerintah Daerah.

(2) Insentif yang merupakan perangkat atau upaya untuk memberikan imbalan terhadap pelaksanaan kegiatan yang sejalan dengan rencana tata ruang berupa :

a. keringanan pajak, pemberian kompensasi, subsidi silang, imbalan, sewa ruang, dan urun saham;

b. pembangunan serta pengadaan infrastruktur;

c. kemudahan prosedur perizinan; dan/atau

d. pemberian penghargaan kepada masyarakat, swasta dan/atau Pemerintah Daerah.

(3) Disinsentif yang merupakan perangkat untuk mencegah, membatasi pertumbuhan, atau mengurangi kegiatan yang tidak sejalan dengan rencana tata ruang berupa :

a. pengenaan pajak yang tinggi yang disesuaikan dengan besarnya biaya yang dibutuhkan untuk mengatasi dampak yang ditimbulkan akibat pemanfaatan ruang;

b. pembatasan penyediaan infrastruktur, pengenaan kompensasi, dan penalti.

(4) Insentif dan disinsentif diberikan dengan tetap menghormati hak masyarakat.

\section{Pasal 39}

Pengenaan sanksi merupakan tindakan penertiban yang dilakukan terhadap pemanfaatan ruang yang tidak sesuai dengan rencana tata ruang dan peraturan zonasi.

\section{Pasal 61 :}

Dalam pemanfaatan ruang, setiap orang wajib :

a. mentaati rencana tata ruang yang telah ditetapkan; 
b. memanfaatkan ruang sesuai dengan izin pemanfaatan ruang dari pejabat yang berwenang;

c. mematuhi ketentuan yang ditetapkan dalam persyaratan izin pemanfaatan ruang;

d. memberikan akses terhadap kawasan yang oleh ketentuan peraturan perundangundangan dinyatakan sebagai milik umum.

\section{Peraturan Pemerintah Nomor 36 Tahun 2005 tentang Peraturan Pelaksanaan Bangunan Gedung}

Ketentuan yang bertautan dengan pemberian sanksi atas pelanggaran dalam pelaksanaan pembangunamn gedung, adalah :

\section{Pasal 6}

(1) Fungsi dan klasifikasi bangunan gedung harus sesuai dengan peruntukan lokasi yang diatur dalam RTRW Kabupaten/Kota, RDTRKP dan/atau RTBL.

(2) Fungsi dan klasifikasi bangunan gedung diusulkan oleh pemiliki bangunan gedung dalam pengajuan permohonan izin mendirikan bangunan.

\section{Keputusan Presiden No. 32 Tahun 1990 tentang Pengelolaan Kawasan Lindung}

Ketentuan dalam Keppres No. 32 Tahun 1990 yang berkaitan dengan sempadan sungai, adalah :

\section{Pasal 1 ayat (7) :}

Sempadan sungai adalah kawasan sepanjang kiri kanan sungai,temasuk sungai buatan/kanal/saluran irigasi primer, yang mempunyai manfaat penting untuk mempertahankan kelestarian fungsi sungai.

\section{Pasal 15 :}

Perlindungan terhadap sempadan sungai dilakukan untuk melindungi sungai dari kegiatan manusia yang dapat mengganggu dan merusak kualitas air sungai, kondisi fisik pinggir dan dasar sungai serta mengamankan aliran sungai.

\section{Pasal 16 :}

Kriteria sempadan sungai adalah :

a. Sekurang-kurangnya 100 meter di kiri kanan sungai besar dan 50 meter di kiri kanan anak sungai yang berada di luar permukiman. 
b. Untuk sungai di kawasan permukiman berupa sempadan sungai yang diperkirakan cukup untuk dibangun jalan inspeksi antara 10-15 meter.

Pasal 37 ayat (1) :

Di dalam kawasan lindung dilarang melakukan kegiatan budidaya, kecuali yang tidak mengganggu fungsi lindung.

\section{Peraturan Menteri Pekerjaan Umum Nomor 63/PRT/1993 tentang Garis Sempadan Sungai, Daerah Manfaat Sungai, Daerah Penguasaan Sungai dan Bekas Sungai. \\ Ketentuan dalam Peraturan Menteri Pekerjaan Umum yang bertautan dengan sempadan sungai adalah :}

\section{Pasal 1 angka 9 :}

Sungai adalah tempat-tempat dan wadah-wadah serta jaringan pengaliran air mulai dari mata air sampai muara dengan dibatasi kanan kirinya serta sepanjang pengalirannya oleh garis sempadan.

\section{Pasal 1 angka 10 :}

Garis Sempadan Sungai adalah garis batas luar pengamanan sungai.

\section{Pasal 1 angka 11 :}

Daerah Sempadan adalah kawasan sepanjang kiri kanan sungai termasuk sungai buatan, yang mempunyai manfaat penting untuk mempertahankan kelestarian fungsi sungai.

\section{Pasal 1 angka 18 :}

Tanggul adalah bangunan pengendali sungai yang dibangun dengan persyaratan teknis tertentu untuk melindungi daerah sekitar sungai terhadap limpasan air sungai.

\section{Pasal 5 :}

Kriteria penatapan garis sempadan sungai terdiri dari :
a. Sungai bertanggul di luar kawasan perkotaan
b. Sungai bertanggul di dalam kawasan perkotaan
c. Sungai tidak bertanggul di luar kawasan perkotaan
d. Sungai tidak bertanggul di dalam kawasan perkotaan

Pasal 6 ayat (1) :

Garis Sempadan Sungai Bertanggul ditetapkan sebagai berikut : 
a. Garis Sempadan Sungai Bertanggul di luar kawasan perkotaan ditetapkan sekurang-kurangnya 5 meter di sebelah luar sepanjang kaki tanggul.

b. Garis Sempadan Sungai Bertanggul di dalam kawasan perkotaan ditetapkan sekurang-kurangnya 3 meter di sebelah luar sepanjang kaki tanggul.

\section{Pasal 7 ayat (1) :}

Penetapan Garis Sempadan Sungai Tak Bertanggul di luar kawasan perkotaan didasarkan pada kriteria :

a. Sungai besar, yaitu sungai yang mempunyai daerah pengaliran sungai seluas $500 \mathrm{~km} 2$ atau lebih.

b. Sungai kecil, yaitu sungai yang mempunyai daerah pengaliran sungai seluas kurang dari $500 \mathrm{~km} 2$.

\section{Pasal 7 ayat (3) :}

Garis Sempadan Sungai Tidak Bertanggul di luar kawasan perkotaan pada sungai besar ditetapkan sekurang-kurangnya 100 meter, sedangkan pada sungai kecil sekurang-kurangnya 50 meter dihitung dari tepi sungai pada waktu ditetapkan.

\section{Pasal 8 :}

Penetapan garis sempadan sungai tak bertanggul di dalam kawasan perkotaan didasarkan pada kriteria :

a. Sungai yang mempunyai kedalaman tidak lebih dari 3 meter, garis sempadan ditetapkan sekurang-kurangnya 10 meter dihitung dihitung dari tepi sungai pada waktu ditetapkan.

b. Sungai yang mempunyai kedalaman lebih dari 3 meter sampai dengan 20 meter, garis sempadan ditetapkan sekurang-kurangnya 15 meter dihitung dari tepi sungai pada waktu ditetapkan.

c. Sungai yang mempunyai kedalaman maksimum lebih dari 20 meter, garis sempadan sungai sekurang-kurangnya 30 meter dihitung dari tepi sungai pada waktu ditetapkan.

\section{Pasal 11 ayat (1) :}

Pemanfaatan lahan di daerah sempadan dapat dilakukan oleh masyarakat untuk kegiatan-kegiatan tertentu sebagai berikut :

a. Untuk budidaya pertanian, dengan jenis tanaman yang diizinkan; 
b. Untuk kegiatan niaga, penggalian dan penimbunan.

c. Untuk pemasangan papan reklame, papan penyuluhan dan peringatan, serta rambu kerja.

d. Untuk pemasangan rentangan kabel listrik, kabel telepon dan pipa air minum.

e. Untuk pemancangan tiang atau pondasi prasarana jalan/jembatan baik umum maupun kereta api.

f. Untuk penyelenggaraan kegiatan yang bersifat sosial dan kemasyarakatan yang tidak menimbulkan dampak merugikan bagi kelestarian dan keamanan fungsi serta fisik sungai.

g. Untuk pembangunan prasarana lalu lintas air dan bangunan pengambilan dan pembuangan air.

\section{Pasal 11 ayat $(2$ :}

Pelaksanaan ketentuan sebagaimana dalam ayat (1) harus memperoleh izin terlebih dahulu dari pejabat yang berwenang aau pejabat yang ditunjuk olehnya, serta memenuhi syarat-syarat yang ditentukan.

\section{Pasal 11 ayat (3) :}

Pejabat yang berwenang dapat menetapkan suatu ruas di daerah sempadan untuk membangun jalan inspeksi dan/atau bangunan sungai yang diperlukan, dengan ketentuan lahan milik perorangan yang diperlukan diselesaikan melalui pembebasan tanah.

\section{Pasal 12 ;}

Pada daerah sempadan dilarang :

a. Membuang sampah, limbah padat dan/atau cair.

b. Mendirikan bangunan permanen untuk hunian dan tempat usaha.

\section{Pasal 14 ayat (1) :}

Masyarakat dapat memanfaatkan lahan di daerah manfaat sungai dengan ketentuan sebagai berikut :

a. Memenuhi persyaratan yang telah ditentukan.

b. Harus dengan izin pejabat yang berwenang.

c. Mengikuti ketentuan yang ditetapkan.

d. Tidak mengganggu upaya pembinaan sungai. 


\section{Peraturan Daerah Propinsi Daerah Tingkat I Jawa Timur Nomor 11 Tahun 1991 tentang Penetapan Kawasan Lindung di Propinsi Daerah Tingkat I Jawa Timur \\ Ketentun dalam Peraturan Daerah Propinsi Daerah Tingkat I Jawa Timur} Nomor 11 Tahun 1991 tentang Penetapan Kawasan Lindung di Propinsi Daerah Tingkat I Jawa Timur yang ada tautannya dengan sempadan sungai adalah :

\section{Pasal 1 huruf $x$ :}

Sungai adalah tempat-tempat dan wadah-wadah serta jaringan pengaliran air mulai dari mata air sampai muara dengan dibatasi kanan kirinya serta sepanjang pengalirannya oleh garis sempadan.

\section{Pasal 1 huruf cc :}

Sempadan sungai adalah kawasan sepanjang kiri kanan sungai termasuk sungai buatan/kanal/saluran irigasi primer, yang mempunyai manfaat penting untuk mempertahankan kelestarian fungsi sungai.

\section{Pasal 12 :}

Sempadan sungai sebagaimana dimaksudkan dalam pasal 5 huruf b ditetapkan dengan kriteria sebagai berikut :

a. Pada sungai besar di luar kawasan permukiman ditetapkan sekurang-kurangnya 100 meter.

b. Pada anak-anak sungai di luar kawasan permukiman ditetapkan sekurangkurangnya 50 meter.

c. Pada sungai besar dan anak sungainya di kawasan permukiman ditetapkan 15 meter.

\section{Pasal 13 :}

Perlindungan dan Sempadan Sungai yang ditetapkan berdasarkan kriteria pasal 12 :

a. Untuk sungai bertanggul diukur dari kiri dan kanan kaki tanggul bagian luar sepanjang yanggul sungai. 
b. Untuk sungai yang tidak bertanggul diukur dari titik banjir tertinggi ke arah daratan.

\section{Pembahasan}

Studi ini masuk dalam kategori doctrinal research melalui pendekatan kasus (Marzuki; 2005) dengan cara mendeskripsikan lebih lanjut ketentuan dalam regulasi dengan pengalaman empiris yang pernah dilakukan pada kasus sejenis.

Strategi pengendalian dan pengawasan sempadan Kali Surabaya di Kecamatan Wringin Anom dan Kecamatan Driyorejo merujuk pada ketentuan pengendalian pemanfaatan ruang berdasarkan ketentuan Undang-undang Nomor 26 Tahun 2007 tentang Penataan Ruang, yaitu ; (1) melalui peraturan zonasi; (2) melalui perizinan; (3) melalui pemberian insentif dan disinsentif; dan (4) melalui pemberian sanksi. Strategi pengendalian dan pengawasan tidak dapat berjalan dengan baik tanpa adanya pemahaman yang jelas dari aparat yang bertanggung jawab dalam pengendalian, pengawasan dan penegakan hukum, terhadap substansi pelanggaran. Oleh karena itu secara periodik perlu dilakukan pelatihan kepada aparat agar mempunyai pandangan yang sama terhadap pelanggaran pemanfaatan ruang di daerah sempadan sungai (Dinas Pekerjaan Umum dan Tata Ruang Kabupaten Gresik; 2013). Langkah-langkahnya adalah sebagai berikut :

\section{Pengendalian dan Pengawasan Melalui Peraturan Zonasi}

Menurut Peraturan Menteri Pekerjaan Umum Nomor 20 Tahun 2011 tentang RDTR dan Peraturan Zonasi, RDTR dan Peraturan Zonasi yang sudah di-perdakan merupakan dokumen rencana tata ruang yang menjadi rujukan untuk menerbitkan Izin Mendirikan Bangunan. Dalam hal ini :

a. Daerah yang sudah memiliki RDTR dan Peraturan Zonasi yang sudah diperda-kan, telah memiliki landasan hukum yang kuat untuk menerbitkan perizinan pembangunan khususnya Izin Mendirikan Bangunan.

b. Daerah yang belum memiliki RDTR dan Peraturan Zonasi yang sudah diperda-kan, tidak memiliki rujukan hukum untuk menerbitkan Izin Mendirikan Bangunan. Pada umumnya yang digunakan sebagai rujukan 
adalah Rencana Tata Ruang Wilayah (RTRW) Kabupaten/Kota dan/atau rencana tata ruang lama yang belum tentu sesuai dengan perkembangan terbaru di lapangan.

Pemerintah Kabupaten Gresik telah memiliki RDTR Kecamatan Driyorejo dan Kecamatan Wringin Anom tetapi formatnya belum sesuai dengan ketentuan dalam Peraturan Menteri Pekerjaan Umum Nomor 20 Tahun 2011 tentang RDTR dan Peraturan Zonasi. Dalam RTRW Kabupaten Gresik (sudah diperda-kan) pemanfaatan ruang di daerah sempadan Kali Surabaya sudah ditetapkan sebagai kawasan perlindungan setempat yang direncanakan untuk ruang terbuka hijau. Artinya pemanfaatan ruang selain ruang terbuka hijau tidak diizinkan berada di daerah sempadan Kali Surabaya. Karena skalanya yang sangta besar ( 1 : 50.000) arahan RTRW Kabupaten Gresik harus segera dijabarkan dalam rencana tata ruang yang lebih rinci, yaitu RDTR dan Peraturan Zonasi. Strategi yang ditempuh dalam rangka pengendalian daerah sempadan Kali Surabaya melalui peraturan zonasi adalah :

a. Sesegera mungkin menyusun RDTR dan Peraturan Zonasi di Kecamatan Driyorejo dan Kecamatan Wringin Anom dengan format sesuai ketentuan Peraturan Menteri Pekerjaan Umum Nomor 20 Tahun 2011 tentang RDTR dan Peraturan Zonasi.

b. Di dalam RDTR dan Peraturan Zonasi harus disebutkan dengan jelas dalam Zoning Map dan Zoning Text, batas-batas daerah sempadan Kali Surabaya secara definitif dalam peta berskala $1: 5.000$.

c. RDTR dan Peraturan Zonasi yang disusun harus segera di-perda-kan agar dapat digunakan sebagai rujukan dalam penerbitan perizinan pembangunan.

\section{Pengendalian dan Pengawasan Melalui Perizinan}

Menurut Peraturan Pemerintah Nomor 15 Tahun 2010 tentang Penyelenggaraan Penataan Ruang; dalam pemanfaatan ruang setiap orang wajib memiliki izin pemanfaatan ruang. Izin pemanfaatan ruang dapat berupa :

a. Izin Prinsip 
Izin prinsip adalah surat izin yang diberikan pemerintah/pemerintah daerah untuk menyatakan suatu kegiatan secara prinsip diperkenankan untuk diselenggarakan atau beroperasi.

b. Izin Lokasi

Izin lokasi adalah izin yang diberikan kepada pemohon untuk memperoleh ruang yang diperlukan dalam rangka melakukan aktivitasnya. Izin lokasi diperlukan untuk pemanfaatan ruang lebih dari satu Ha untuk kegiatan bukan pertanian, dan lebih dari $25 \mathrm{Ha}$ untuk kegiatan pertanian.

c. Izin Tata Ruang/Blok Plan adalah izin teknis tentang tata bangunan dan tata lingkungan yang diberikan oleh Pemerintah Daerah kepada badan usaha atau perorangan untuk menata wujud struktur dan pola penggunaan ruang.

d. Izin Mendirikan Bangunan (IMB)

Izin Mendirikan Bangunan merupakan dasar dalam mendirikan bangunan dalam rangka pemanfaatan ruang. IMB diberikan berdasarkan peraturan zonasi sebagai dasar bagi pemegang izin untuk mendirikan bangunan sesuai fungsi yang telah ditetapkan, dan rencan ateknis bangunan gedung yang telah disetujui oleh pemerintah daerah kabupaten/kota.

e. Izin lainnya berdasarkan ketentuan perundang-undangan (antara lain Izin Perubahan Pemanfaatan Ruang, Izin Gangguan).

Di Kabupaten Gresik, instansi yang berwenang menerbitkan semua perizinan pembangunan adalah Badan Penanaman Modal dan Perizinan (BPMP). Penerbitan perizinan yang dipusatkan hanya pada satu instansi membutuhkan koordinasi yang baik dengan instansi lain, yaitu Badan Perencanaan Pembangunan Daerah, Badan Pertanahan Nasional, Dinas Pekerjaan Umum dan Tata Ruang. Dalam kaitannya dengan pemanfaatan ruang di daerah sempadan Kali Surabaya dibutuhkan rekomendasi teknis dari Balai Besar Wilayah Sungai (BBWS) Brantas. Tidak atau kurang lancarnya koordinasi dan pemberian rekomendasi teknis dari instansi teknis yang lain menyebabkan pemanfaatan ruang menjadi tidak terkendali, karena perkembangan di lapangan lebih cepat dibandingkan dengan proses perizinan. BBWS mempunyai kewenangan untuk mengendalikan pemanfaatan ruang di daerah sempadan Kali 
Surabaya, tetapi tidak dapat mengeksekusi melalui perizinan dan penertiban karena bukan kewenangannya. Demikian pula jika terjadi pembangunan gedung di daerah sempadan sungai, BBWS tidak berwenang melakukan penindakan hukum.

Berkaitan dengan permasalahan yang dihadapi, strategi yang ditempuh adalah :

a. Dalam menerbitkan perizinan, Badan Penanaman Modal dan Perizinan harus mendapatkan rekomendasi teknis terlebih dahulu dari instansi teknis yang memiliki kompetensi di bidang bersangkutan. Untuk menerbitkan Izin prinsip perlu rekomendasi teknis dari Badan Perencanaan Pembangunan Daerah; untuk penerbitan Izin Lokasi perlu rekomendasi dari Badan Pertanahan Nasional. Untuk menerbitkan Izin Blok Plan dan Izin Mendirikan Bangunan (IMB) harus mendapat rekomendasi teknis dari Dinas Pekerjaan Umum dan Tata Ruang. Untuk menerbitkan semua perizinan pada lokasi yang berbatasan dengan Kali Surabaya harus mendapat rekomendasi teknis dari Balai Besar Wilayah Sungai (BBWS) Brantas.

b. Izin harus diterbitkan secara berurutan, bukan paralel.

Pengajuan Izin Lokasi dapat diproses apabila Izin Prinsip sudah diterbitkan. Pengajuan Izin Blok Plan atau Izin Site Plan dapat diproses apabila Izin Lokasi sudah diterbitkan. Pengajuan IMB dapat diproses apabila Izin Blok Plan sudah diterbitkan. Dalam hal ini proses pengajuan perizinan tidak dapat diparalel. Jika hal ini dilakukan, maka berpeluang terjadi penyimpangan dan/atau ketidaksesuaian, karena ketentuan yang ditetapkan dalam perizinan yang lebih tinggi tingkatannya belum final dan masih dapat berubah. Dengan pengertian lain, perizinan yang lebih tinggi tingkatannya menjadi referensi bagi perizinan pada tingkatan di bawahnya.

c. Semua perizinan yang diterbitkan harus merujuk pada rencana tata ruang yang sama (yang sudah di-perda-kan).

d. Apabila menghadapi masalah krusial, harus dilakukan koordinasi lintas sektoral untuk mendapatkan kesamaan pandang dalam penyelesaian masalah. 


\section{Pengendalian dan Pengawasan Melalui Pemberian Insentif dan Disinsentif}

Menurut Undang-undang Nomor 26 Tahun 2007 Tentang Penataan Ruang, insentif diberikan untuk kegiatan pemanfaatan ruang yang didorong pengembangannya sesuai rencana tata ruang, sedang disinsentif diberikan untuk kegiatan pemanfaatan ruang yang dihambat pengembangannya..

\section{a. Pemberian Insentif}

Insentif dapat berupa insentif fiskal dan/atau insentif non fiskal.

(1) Insentif fiskal dapat berupa : pemberian keringanan pajak; dan/atau pengurangan retribusi. Pemberian insentif fiskal harus dilaksanakan sesuai dengan ketentuan perundang-undangan.

(2) Insentif non fiskal dapat berupa : pemberian kompensasi; subsidi silang; kemudahan perizinan; imbalan; sewa ruang; urun saham; penyediaan sarana dan sarana; penghargaan; dan/atau publikasi atau promosi. Ketentuan mengenai pemberian insentif non fiskal diatur oleh menteri yang menyelenggarakan urusan pemerintahan terkait dengan bidang insentif yang diberikan.

Insentif dari Pemerintah dan/atau Pemerintah Daerah kepada masyarakat, dapat berupa :

(1). Pemberian keringanan pajak

(2). Pemberian kompensasi

(3). Pengurangan retribusi.

(4). Imbalan.

(5). Sewa ruang.

(6). Urun saham.

(7). Penyediaan prasaranadan/atau sarana.

(8). Kemudahan periizinan.

Agar mendapatkan kepastian hukum, mekanisme pemberian insentif diatur dalam peraturan yang mengikat semua pemangku kepentingan. Mekanisme pemberian insentif yang berasal dari Pemerintah Daerah Kabupaten/ Kota diatur dengan peraturan bupati/peraturan walikota. 


\section{b. Pemberian Disinsentif}

Disinsentif dapat berupa disinsentif fiskal dan/atau disinsentif non fiskal.

(1) Disinsentif fiskal berupa pengenaan pajak yang tinggi.

(2) Disinsentif non fiskal berupa : kewajiban memberi kompensasi; persyaratan khusus dalam perizinan; kewajiban memberi imbalan; dan/atau pembatasan penyediaan sarana dan prasarana.

Disinsentif dari Pemerintah dan/atau Pemerintah Daerah kepada masyarakat, dapat berupa :

(1). Kewajiban memberikan kompensasi.

(2). Persyaratan khusus dalam perizinan bagi kegiatan pemanfaatan ruang yang diberikan oleh Pemerintah dan Pemerintah Daerah.

(3). Kewajiban memberikan imbalan.

(4). Pembatasan penyediaan sarana dan prasarana.

(5). Persyaratan khusus dalam perizinan.

Mekanisme pemberian disinsentif yang berasal dari Pemerintah Daerah Kabupaten/ Kota diatur dengan peraturan walikota.

Dalam kaitannya dengan pengendalian dan pengawasan pemanfaatan ruang di daerah sempadan Kali Surabaya, strategi yang dilakukan adalah :

a. Memberikan insentif kepada pemilik bangunan yang bersedia menyesuaikan bangunannya dengan ketentuan rencana tata ruang. Antara lain pemilik bangunan yang bersedia memundurkan bangunannya mengikuti Garis Sempadan Sungai yang ditetapkan dalam rencana tata ruang. Insentif diberikan dalam bentuk kemudahan pemberian IMB, penyediaan jalan inspeksi yang sekaligus dapat digunakan untuk jalur sirkulasi warga.

b. Memberikan disinsentif kepada pemilik bangunan yang melanggar Garis Sempadan Sungai. Disinsentif diberikan dalam bentuk tidak memberikan IMB pada bagian yang melanggar Garis Sempadan Sungai dengan catatan, bagian yang melanggar sempadan sungai sewaktu-waktu dapat dibongkar oleh Pemerintah Daerah.

\section{Pengendalian dan Pengawasan Melalui Pemberian Sanksi}

Jenis sangsi administratif dapat berupa : 


\section{a. Peringatan tertulis.}

Peringatan tertulis dilakukan melalui penerbitan surat peringatan tertulis dari pejabat yang berwenang. Surat peringatan tertulis memuat :

(1) Rincian pelanggaran pemanfaatan ruang.

(2) Kewajiban untuk menyesuaikan kegiatan pemanfaatan ruang dengan rencana tata ruang dan ketentuan teknis pemanfaatan ruang.

(3) Tindakan pengenaan sangsi yang akan diberikan sesuai dengan ketentuan perundang-undangan.

Surat peringatan tertulis diberikan paling banyak tiga kali, yang masingmasing diterbitkan dengan rentang waktu tertentu sesuai dengan ketentuan peraturan perundang-undangan. Apabila peringatan tertulis diabaikan, pejabat berwenang melakukan tindakan pengenaan sangsi sesuai dengan urutan selanjutnya.

\section{b. Penghentian sementara kegiatan.}

Penghentian sementara kegiatan dilakukan melalui tahapan :

(1) Pejabat berwenang menerbitkan peringatan tertulis.

(2) Apabila peringatan tertulis diabaikan, pejabat berwenang menerbitkan surat keputusan penghentian sementara kegiatan pemanfaatan ruang.

(3) Berdasarkan surat keputusan tersebut pejabat berwenang melakukan penghentian sementara kegiatan pemanfaatan ruang secara paksa.

(4) Setelah kegiatan pemanfaatan ruang dihentikan, pejabat berwenang melakukan pengawasan agar kegiatan pemanfaatan ruang yang dihentikan tidak beroperasi kembali sampai dengan terpenuhinya kewajiban pelanggar.

\section{c. Penutupan lokasi.}

Penutupan lokasi dilakukan melalui tahapan sebagai berikut :

(1) Pejabat yang berwenang menerbitkan surat peringatan tertulis.

(2) Apabila surat peringatan tertulis diabaikan, pejabat berwenang menerbitkan surat keputusan penutupan lokasi. 
(3) Berdasarkan surat keputusan penutupan lokasi, pejabat berwenang melakukan penutupan lokasi secara paksa dengan bantuan aparat penertiban.

(4) Setelah dilakukan penutupan lokasi, pejabat berwenang melakukan pengawasan untuk memastikan lokasi yang ditutup tidak dibuka kembali sampai dengan orang yang melakukan pelanggaran tersebut memenuhi kewajibannya.

\section{d. Pencabutan izin.}

Pencabutan izin dilakukan melalui tahapan sebagai berikut :

(1) Pejabat yang berwenang menerbitkan surat peringatan tertulis.

(2) Apabila surat peringatan tertulis diabaikan, pejabat berwenang mencabut izin dengan menerbitkan surat keputusan pencabutan izin.

(3) Berdasarkan surat keputusan pencabutan izin, pejabat berwenang memberitahukan kepada orang yang melakukan pelanggaran mengenai status izin yang telah dicabut sekaligus perintah untuk menghentikan kegiatan pemanfaatan ruang yang telah dicabut izinnnya.

(4) Apabila perintah untuk menghentikan kegiatan pemanfatan ruang diabaikan, pejabat berwenang melakukan tindakan penertiban sesuai dengan ketentuan perundang-undangan.

\section{e. Pembatalan izin.}

Pembatalan izin dilakukan melalui tahapan:

(1) Pejabat yang berwenang menerbitkan surat peringatan tertulis.

(2) Apabila surat peringatan tertulis diabaikan, pejabat berwenang melakukan pembatalan izin, dengan menerbitkan surat keputusan pembatalan izin.

(3) Berdasarkan surat keputusan pembatalan izin, pejabat berwenang memberitahukan kepada orang yang melakukan pelanggaran mengenai status izin yang telah dibatalkan sekaligus perintah untuk menghentikan kegiatan pemanfaatan ruang yang telah dibatalkan izinnnya. 
(4) Apabila perintah untuk menghentikan kegiatan pemanfatan ruang diabaikan, pejabat berwenang melakukan tindakan penertiban sesuai dengan ketentuan perundang-undangan.

\section{f. Pembongkaran bangunan.}

Pembongkaran bangunan dilakukan mnelalui tahapan :

(1) Pejabat yang berwenang menerbitkan surat peringatan tertulis.

(2) Apabila surat peringatan tertulis diabaikan, pejabat berwenang menerbitkan surat keputusan pembongkaran bangunan.

(3) Berdasarkan surat keputusan pembongkaran bangunan, pejabat berwenang melakukan penertiban sesuai dengan ketentuan peraturan perundang-undangan.

\section{g. Denda administratif.}

Denda administratif dapat dikenakan secara tersendiri atau bersama-sama dengan pengenaan sangsi administratif.

\section{h. Pemulihan fungsi ruang.}

Pemulihan fungsi ruang dilakukan melalui tahapan sebagai berikut :

(1) Pejabat yang berwenang menerbitkan surat peringatan tertulis.

(2) Apabila surat peringatan tertulis diabaikan, pejabat berwenang menerbitkan surat perintah pemulihan fungsi ruang.

(3) Berdasarkan surat perintah pemulihan fungsi ruang, pejabat berwenang memberitahukan kepada orang yang melakukan pelanggaran mengenai ketentuan pemulihan fungsi ruang dan cara pemulihan fungsi ruang yang harus dilaksanakan dalam jangka waktu tertentu.

(4) Pejabat berwenang melakukan pengawasan pelaksanaan kegiatan pemulihan ruang.

(5) Apabila jangka waktu yang ditetapkan tidak dapat dipenuhi oleh orang yang melakukan pelanggaran, pejabat berwenang melakukan tindakan pemulihan fungsi ruang secara paksa.

Dalam kaitannya dengan pengendalian dan pengawasan pemanfaatan ruang di daerah sempadan Kali Surabaya, Pemerintah Provinsi Jawa Timur telah memberikan peringatan pertama sampai peringatan ketiga kepada pemilik 
bangunan yang melanggar garis sempadan kali Surabaya. Namun demikian peringatan tersebut tidak ditanggapi oleh pemilik bangunan, dan tidak ada tindakan hukum bagi pelanggar.

Strategi yang ditempuh dalam rangka pemberian sanksi atas pelanggaran garis sempadan Kali Surabaya pada dasarnya harus tetap mengikuti ketentuan yang berlaku, yaitu melalui tahapan sebagaimana ditetapkan dalam Undang-undang Nomor 26 Tahun 2007 tentang Penataan Ruang. Namun demikian langkah pemberian sanksi harus dibarengi dengan pendekatan kepada masyarakat melalui negosiasi untuk mencari penyelesaian yang sama-sama menguntungkan (win-win solution) sejauh masih memungkinkan. Antara lain dengan menyediakan lahan pengganti kepada masyarakat yang bangunannya terkena garis sempadan sungai; menyediakan rumah susun; menata kembali bangunanbangunan di sepanjang tepi sungai dengan menetapkan daerah sempadan sungai sesuai rencana tata ruang sehingga kawasan tepi sungai menjadi kawasan yang tertib, sehat, indah dan taat pada peraturan.

Bagi korporasi yang melanggar ketentuan daerah sempadan sungai diwajibkan untuk mengembalikan bagian yang melanggar ke fungsi semula. Jika tidak, harus dilakukan penegakan hukum sebagaimana dilakukan oleh Satpol Pamong Praja Kabupaten Gresik terhadap Ruko dan Pergudangan City Nine, dimana bagian yang melanggar daerah sempadan Kali Surabaya terpaksa dibongkar.

Agar mampu melakukan pengendalian dan pengawasan terhadap pemanfaatan ruang di daerah sempadan sungai, semua aparat yang terkait harus memiliki pemahaman yang jelas menganai tugas pkok dan fungsinya terutama pemahaman terhadap rencana tata ruang dan permasalahan yang ada. Untuk keperluan tersebut kepada semua aparat yang terkait dengan pengendalian, pengawasan dan penertiban pembangunan harus diberikan pelatihan secara periodik sebagaimana telah dilaksanakan oleh Pemerintah Kabupaten Gresik sejak tahun 2013 sampai sekarang.

\section{Kesimpulan}


Strategi pengendalian dan pengawasan pemanfaatan ruang di daerah Sempadan Kali Surabaya dilakukan melalui :

1. Penetapan rencana tata ruang yang jelas, dalam bentuk dokumen RDTR dan Peraturan Zonasi yang di-perda-kan.

2. Melakukan filter melalui penerbitan izin pembangunan yang harus dilakukan secara berjenjang dan berurutan. Dalam hal ini dilarang mengajukan perizinan pembangunan secara paralel.

3. Memberikan insentif dan disinsentif.

4. Memberikan sanksi secara bertahap, mulai dari pemberian peringatan sampai pembongkaran.

5. Memberikan pelatihan pengendalian, pengawasan dan penertiban, kepada semua aparat yang terkait dengan pemanfaatan ruang secara periodik untuk mendapatkan pemahaman dan kesamaan pandang dalam menghadapi masalah.

\section{Daftar Pustaka}

Ecoton (2014). "Bangunan Liar di Sempadan Akibatkan Kali Surabaya Menyempit”. http://www.surabaya.tribunnews.com. Diakses tanggal 3 Juni 2014 Jam 20.30 WIB.

Marzuki, Peter, Mahmud, Prof. Dr. SH. MS. LLM. (2005). "Penelitian Hukum". Prenada Media Group. Jakarta.

Dinas Pekerjaan Umum dan Tata Ruang Kabupaten Gresik (2013). "Petunjuk Teknis Pemanfaatan dan Pengelolaan Kawasan Peruntukan Industri”.

Dinas Pekerjaan Umum dan Tata Ruang Kabupaten Gresik (2013). "Petunjuk Teknis Pemanfaatan dan Pengelolaan Kawasan Peruntukan Permukiman”.

Pemerintah Republik Indonesia (2007). 'Undang-undang Nomor 26 Tahun 2007 Tentang Penataan Ruang”.

Pemerintah Republik Indonesia (2005). "Peraturan Pemerintah Nomor 36 Tahun 2005 tentang Peraturan Pelaksanaan Undang-undang Nomor 28 Tahun 2002 tentang Bangunan Gedung”. 
225 - Strategi Pengedalian dan Pengawasan Sempadan Sungai,......

Presiden Republik Indonesia (1990). "Keputusan Presiden No. 32 Tahun 1990 tentang Pengelolaan Kawasan Lindung

Departemen Pekerjaan Umum (1993). "Peraturan Menteri Pekerjaan Umum Nomor 63/PRT/1993 tentang Garis Sempadan Sungai, Daerah Manfaat Sungai, Daerah Penguasaan Sungai dan Bekas Sungai.

Pemerintah Daerah Propinsi Daerah Tingkat I Jawa Timur (1991). "Peraturan Daerah Propinsi Daerah Tingkat I Jawa Timur Nomor 11 Tahun 1991 tentang Penetapan Kawasan Lindung di Propinsi Daerah Tingkat I Jawa Timur

Perusahaan Umum Jasa Tirta (1994). “Studi Tata Guna Tanah Sepanjang Kiri Kanan Kali Surabaya, Kali Wonokromo dan Kali kedurus. Laporan Penelitian Kerjasama Perum Jasa Tirta dan Jurusan Teknik Sipil FTSP-ITS.

*) Pengajar pada UPM Sosial Humaniora ITS 